\title{
Energy Retrofitting of the Mediterranean Terrace Dwellings
}

\author{
D.K.SERGHIDES M.MARKIDES \& M.C.KATAFYGIOTOU \\ Department of Environmental Science and Technology Cyprus University of Technology (CUT) Limassol, Cyprus \\ despina.serghides@cut.ac.cy, markidesmarina@gmail.com, martha.katafygiotou@cut.ac.cy
}

\begin{abstract}
The building sector in Europe is responsible for an estimated $40 \%$ of the total energy consumption. This paper focuses on the existing terrace housing in Mediterranean island of Cyprus. The collection of statistical data and the building typologies were developed based on a harmonised structure for European building typologies according to the IEE EPISCOPE project.
\end{abstract}

A representative terrace-housing complex was used as a showcase for demonstrating the energy performance and the potential of energy savings, by applying energy conservation measures. This research aims at filling in the current knowledge gap. It also portrays that building typologies can be a useful instrument to facilitate the energy performance assessment of the building stock.

Keywords - Energy performance, Building typology, Terrace housing, Existing building stock.

\section{INTRODUCTION}

The increasing energy consumption already threatens the future of the planet, as studies show that $10 \%$ of the world population exploits $90 \%$ of energy resources [1]. Under this threat, the European Union aims to achieve a more sustainable future and therefore focuses on the existing building stock by identifying the potential energy conservation of the building sector. However this venture presents many obstacles and it seems very difficult to find data on the European or on the national levels [2].

In 2000 , it was estimated that $45 \%$ of the energy produced in Europe was used in the building sector and $50 \%$ of air pollution was caused by this sector [3]. The existing residential building stock exceeds the number of newly built dwellings in most developed countries. Moreover residential buildings are responsible for approximately $2 / 3$ of the energy consumption of the building sector [4]. While new buildings add at most $1 \%$ per year to the existing stock, the other $99 \%$ of the buildings are already built and produce about $26 \%$ of the energy-use induced carbon emissions [5]. Thus, there is greater potential of energy savings and reduction of carbon emissions, in the existing residential buildings than the newly built ones.The improvement of the energy performance of the existing residential stock in every country is essential since the operational cost; the energy consumption and the carbon dioxide emissions are major issues worldwide. This paper is based on information laid out by the European, IEE Episcope Project [6]. The study focuses on the Terrace Family House (TFH) typology, which is one of the main residential typologies identified in Cyprus; three representative buildings from this typology were selected to conduct the research. This paper is a multiple case study and aims at reducing the energy consumption and $\mathrm{CO}_{2}$ emissions of the dwelling through energy efficient refurbishment measures.

\section{METHODOLOGY}

According to previous studies by the EU, IEE Project EPISCOPE [6], twelve residential building stock typologies were established as typical and representative of the national residential building stock in Cyprus. These are classified according to their chronological period of construction and their architectural and constructional characteristics. The three building typologies consist of; the Multi-storey Family Houses (MFH), the Terrace Family Houses (TFH) and the Single Family Houses (SFH). These are divided into four different chronological periods, supported by the data collected from the Cyprus Statistical Service [7]. Each chronological division was defined based on the different constructional regulations and techniques that were applicable throughout the years, formulating the four distinctive chronological categories, before 1980 , between 1981 2006, between 2007-2013 and after 2014. These divisions were also guided by the rapid growth of the construction industry in Cyprus, which occurred after 1980 , by the adoption of the European Directive in 2007 [9] and the amendment of the Directive, which was enforced in beginning of 2014 .

For the purpose of this paper only, one residential building typology is examined; the Terrace Family House of the second chronological period between 
1981-2006. Three exemplary building units were selected from a Terrace Family House complex; the middle one and the two end dwellings. These building units have the same constructional characteristics, the same electromechanical systems and they are typical and representative samples for their construction period. The scope of the study is to compare the energy performance concerning the varied location of the buildings (one fully attached house in the middle of the complex and two semi-detached on either end, which have different orientations). The effect of the orientation and the dissimilar exposed facades of the three houses are examined and conclusions towards the energy consumption of the building are derived.

The buildings' design, specifically their construction characteristics, are selected through field inspections and are examined through parametric simulations using the software iSBEMcy. This is the official governmental software used for the categorization of energy efficiency in buildings and also for the calculation of $\mathrm{CO}_{2}$ emissions according to the European Directive 2002/91/EC [8]. The software calculates the energy consumption of the building and concludes to its energy performance certificate, which states the energy categorization of the building. All the European member countries have similar software in order to examine the energy classification of their buildings. Energy rating of a building can provide useful information on its energy consumption. The rating is performed through standard measurements under a specific experimental protocol.

The total area of each building, the heated living volume and the other elements that form the building envelope were documented. Specifically, the characteristics of the roof, the wall, the floor slab, the frame structure and the openings were recorded. Their U-Value as well as their thermal capacity was calculated. The installed electromechanical systems were documented, their energy efficiency investigated and documented in the simulation as well. Due to the lack of the available data, mainly concerning the existing electromechanical systems installed in the representative buildings, certain assumptions were made concerning length, type of pipes and condition of the systems.

The energy auditing of the buildings under study investigates the aspects that affect their energy efficiency. Initially, the simulations conclude to the energy consumption of the existing building. As energy consumption of a building is affected by its construction elements, alternative strategies and techniques for energy efficiency must be used to create a comfortable indoor environment, which at the same time will achieve energy conservation and reduce the operational cost. Therefore, based on the energy categorization of the buildings, one retrofitting scenario was studied in the simulations.

This scenario concerns the energy conservation measures (ECMs), which were based on the new requirements of the EPBD Directive [9] and were enforced in the beginning of 2014. The retrofitting interventions are restricted on the building envelope, while the electromechanical systems for heating and cooling together with the hot water system remained the same. Finally, the pay-back period of retrofitting interventions was also calculated using the official tool published by the Ministry of Energy, Commerce, Industry and Tourism of Cyprus for the cost optimal [10] EMCs.

\section{CASE STUDIES AND RESULTS}

The representative dwellings that were identified and studied concern the Terrace Family House (TFH) typology of the second chronological period (19812006). As shown on Fig. 1, this complex consists of seven Terrace Family Houses (TFH). The chosen buildings for the study are the two end dwellings and the middle one, as illustrated on the Figure. Each building was extensively studied. Information regarding the size, the heated living volume and the thermal characteristics of the building envelope were documented. Furthermore, the characteristics of the heating and cooling systems were recorded.

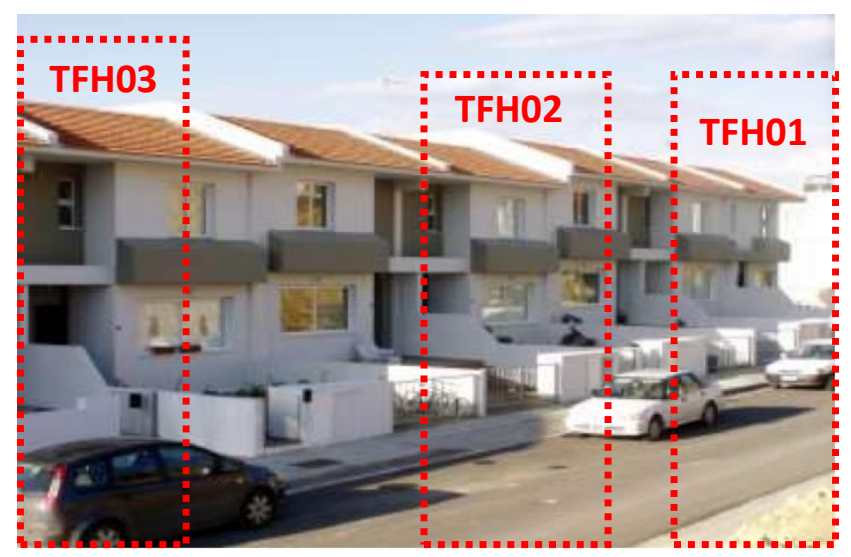

Fig .1. The TFH complex under study 


\section{A. Existing condition of buildings}

The Terrace Family Housing Complex (TFH) is located in the capital City of Nicosia, situated in the inland area of the island. It belongs to the second chronological period between 1981-2006 and was built in the early 2000's. The dwellings have a noninsulated tiled pitched roof with horizontal ceiling, rendered brick walls, the floor slabs in contact with the ground and aluminum-framed single glazed windows. Nowadays, owners of the dwellings replaced their windows with double glazed windows for better indoor comfort and more energy efficiency. The houses have a living room, a dining room, one kitchen, a small WC on the ground floor, three bedrooms and a family bathroom on the first floor. They have an un-insulated constant temperature oil boiler, with a water storage tank, which is connected to the solar thermal panels on the roof and backed up by an electric element for domestic hot water. The cooling system installed is a standard air-conditioning with split units installed in the living room, kitchen and bedrooms of the houses. The thermal characteristics of the building envelope for the TFH and specifically their U-Values are calculated as shown on Table 1.

Table 1. THERMAL CHARACTERISTICS OF THE BUILDING ENVELOPE FOR TFH

\begin{tabular}{|c|c|}
\hline Construction Element & U-Value $\mathbf{W} /\left(\mathbf{m}^{\mathbf{2}} \mathbf{k}\right)$ \\
\hline Pitched roof with horizontal ceiling & 3.42 \\
\hline External Walls & 1.42 \\
\hline Floor in contact with the ground & 0.91 \\
\hline Double glazed windows & 3.80 \\
\hline
\end{tabular}

The first selected Family House (TFH01) is at the end of the Terrace complex and it has North East to South West orientation, with three windows covering $11 \mathrm{~m} 2$ facing south, as shown on Fig. 2. The total heated living area is $112 \mathrm{~m} 2$, the heated living volume is $705.6 \mathrm{~m} 3$ and it is the second large unit, of the three selected houses of the study.

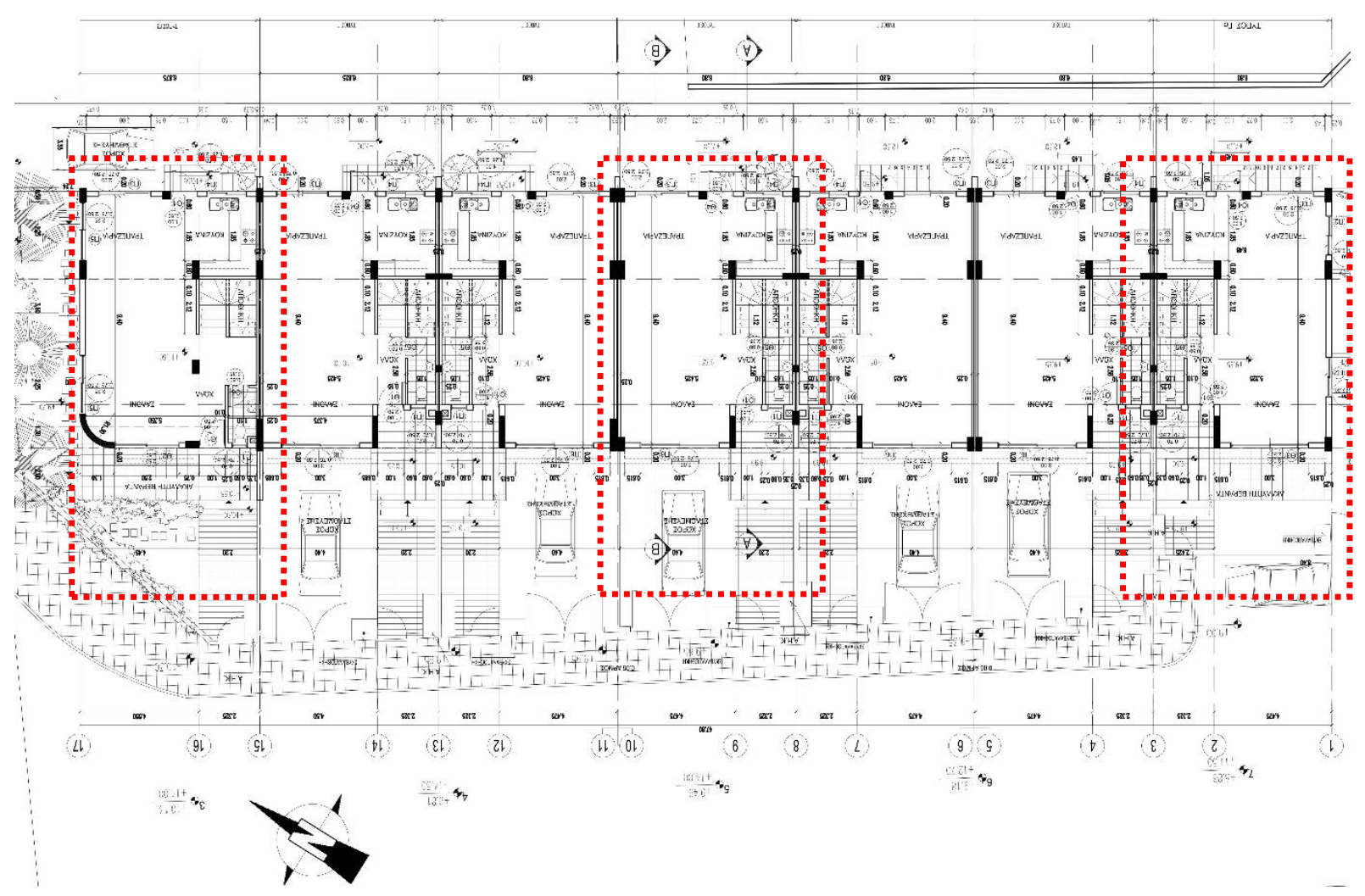

Fig .2. The Architectural plans TFH complex under study

The calculated Total Primary Energy Consumption for the TFH01 is $525.52 \mathrm{kWh} /\left(\mathrm{m}^{2} \mathrm{a}\right), 7 \mathrm{kWh} /\left(\mathrm{m}^{2} \mathrm{a}\right)$ of which are produced from Renewable Energy Sources (RES), the solar thermal panels on the roof for domestic hot water consumption. The total energy consumption for the TFH01 reaches the $248 \mathrm{kWh} /\left(\mathrm{m}^{2} \mathrm{a}\right)$, the energy consumption for heating is
$90.22 \mathrm{kWh} /\left(\mathrm{m}^{2} \mathrm{a}\right)$, for cooling is $136.14 \mathrm{kWh} /\left(\mathrm{m}^{2} \mathrm{a}\right)$, for domestic hot water is $6.36 \mathrm{kWh} /\left(\mathrm{m}^{2} \mathrm{a}\right)$ and for lighting is $15.40 \mathrm{kWh} /(\mathrm{m} 2 \mathrm{a})$, as shown in Fig. 3. The Carbon Dioxide emissions are calculated at $159.60 \mathrm{kgCO}_{2} /\left(\mathrm{m}^{2} \mathrm{a}\right)$. The Energy Performance Certificate (EPC) Categorization falls in class $F$. 


\section{Total Energy Consumption \%}

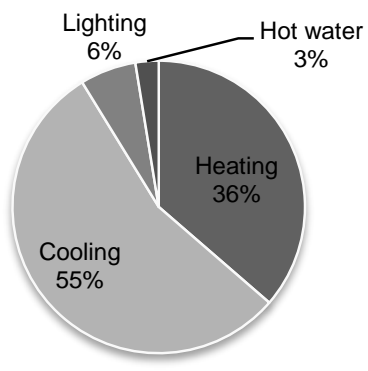

Fig .3. TFH01 Percentage of Total Energy Consumption

The second Family House (TFHO2) is in the middle of the Terrace complex and has a North-East and SouthWest orientation, as shown on Fig. 2. The total heated living area is $110 \mathrm{~m} 2$, whereas the heated living volume is $699.3 \mathrm{~m} 3$. It is the smallest of the three Terrace houses under study.

\section{Total Energy Consumption \%}

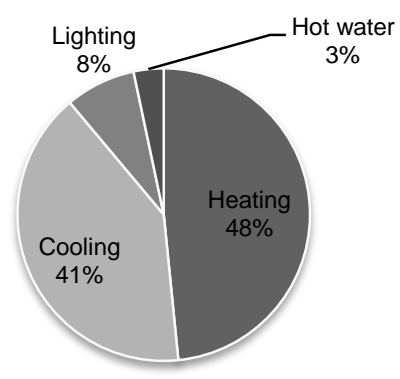

Fig .4. TFH02 Percentage of Total Energy Consumption

The calculated Total Primary Energy Consumption for the TFH02 is $404.42 \mathrm{kWh} /\left(\mathrm{m}^{2} \mathrm{a}\right), 7 \mathrm{kWh} /\left(\mathrm{m}^{2} \mathrm{a}\right)$ of which are produced from Renewable Energy Sources (RES), the solar thermal panels on the roof for domestic hot water consumption. The total energy consumption reaches the $210.31 \mathrm{kWh} /\left(\mathrm{m}^{2} \mathrm{a}\right)$, the energy consumption for heating is $102.14 \mathrm{kWh} /(\mathrm{m} 2 \mathrm{a})$, for cooling is $85.45 \mathrm{kWh} /\left(\mathrm{m}^{2} \mathrm{a}\right)$, for domestic hot water is $7 \mathrm{kWh} /(\mathrm{m} 2 \mathrm{a})$ and for lighting is $16.42 \mathrm{kWh} /\left(\mathrm{m}^{2} \mathrm{a}\right)$, as shown in Fig. 4. The Carbon Dioxide emissions are calculated at $113.06 \mathrm{kgCO}_{2} /\left(\mathrm{m}^{2} \mathrm{a}\right)$. Its Energy Performance Certificate (EPC) Categorization falls in class E. The third Family House (TFH03) is at the end of the Terrace complex and it has a northeast and northwest orientation. It has two large windows and a smaller one covering $14 \mathrm{~m} 2$ facing north, as shown on Fig. 2. The total heated living area is $118.5 \mathrm{~m} 2$, the heated living volume is $746.55 \mathrm{~m} 3$ and it is the largest of the three Terrace houses that are being studied in the research.

Total Energy Consumption \%

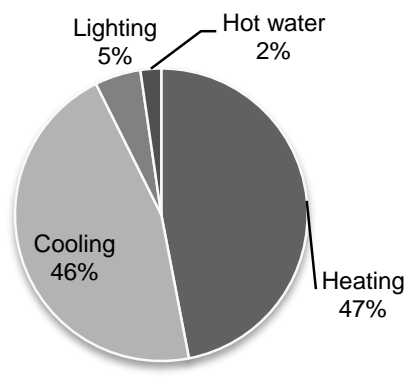

Fig .5. TFH03 Percentage of Total Energy Consumption

The calculated Total Primary Energy Consumption for the TFH03 is $601.16 \mathrm{kWh} /\left(\mathrm{m}^{2} \mathrm{a}\right), 7 \mathrm{kWh} /\left(\mathrm{m}^{2} \mathrm{a}\right)$ of which are produced from Renewable Energy Sources (RES), the solar thermal panels on the roof for domestic hot water consumption. The total final energy consumption for the TFH03 reaches $307.63 \mathrm{kWh} /\left(\mathrm{m}^{2} \mathrm{a}\right)$, from which the energy consumption for heating is $143.40 \mathrm{kWh} /\left(\mathrm{m}^{2} \mathrm{a}\right)$, for cooling is $139.43 \mathrm{kWh} /\left(\mathrm{m}^{2} \mathrm{a}\right)$, for domestic hot water is $9.31 \mathrm{kWh} /\left(\mathrm{m}^{2} \mathrm{a}\right)$ and for lighting is $15.49 \mathrm{kWh} /\left(\mathrm{m}^{2} \mathrm{a}\right)$ as shown in Fig. 5. The Carbon Dioxide emissions are calculated at $168.54 \mathrm{~kg} \mathrm{CO} /\left(\mathrm{m}^{2} \mathrm{a}\right)$. The Energy Performance Certificate (EPC) Categorization falls in class F.

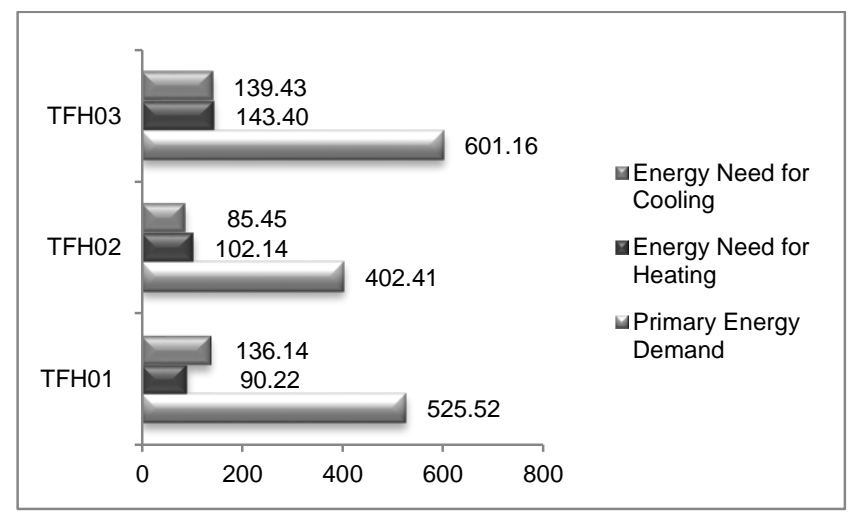

Fig .6. Comparing the Primary Energy Consumption, Energy need for heating and cooling for the existing TFH01, TFH02, TFH03

Through comparative studies of the above results and as indicated in Fig. 6, the energy needs of the third Terrace Family House (TFH03) are the highest followed by the first Terrace Family House (TFH01) and the second Terrace Family House (TFH02) with the lowest. All the three houses have the same 
thermal characteristics and the same HVAC systems. Their only differentiating variables are their orientation, their different exposed surface areas, their heated living areas and their heated living volumes.

Comparing the results of the two end houses of the complex, TFHO1 and TFH03, it is concluded that they fall under the same EPC category F; the TFH03 has a larger heating living area by $6.5 \mathrm{~m} 2$ and therefore a higher primary energy consumption of $68.16 \mathrm{kWh} /(\mathrm{m} 2 \mathrm{a})$, than TFH01. The difference of the primary energy consumption is also attributed to the different orientation of the two houses. More specifically, the TFH01 has windows and exposed surface area facing south, whereas the TFH03 has the same exposed surface area and larger windows facing north and, therefore it has a higher energy consumption for heating due to the lack of solar gains. The differences are accentuated when their heating consumption is compared. The TFH01 has a heating consumption of $90.22 \mathrm{kWh} /(\mathrm{m} 2 \mathrm{a})$; whereas the heating consumption for the THF03 is $143.40 \mathrm{kWh} /(\mathrm{m} 2 \mathrm{a})$.

Comparing their cooling consumption, the difference is not significant; the TFH01 has a cooling consumption of $136.14 \mathrm{kWh} /(\mathrm{m} 2 \mathrm{a})$, which is lower than the $139.43 \mathrm{kWh} /(\mathrm{m} 2 \mathrm{a})$ of the TFH03. The westward orientation causes slightly bigger overheating than the eastward orientation. The results indicate the significant role of the orientation in the buildings' design. In this case study, the TFH01 benefits from the southern sun during the winter and from the cooler breezes of the southwest during the summer, consequently it has an improved energy performance with less energy consumption all over the year. The second Terrace Family House TFH02, situated in the middle of the complex, has the lowest primary energy consumption and energy demand for cooling and heating. It is classified as (E), one class higher than the other two $(F)$. Since it is located in the middle of the terrace complex, it benefits from the adjacent buildings, which act as a buffer on the left and right, and more specifically on the Southeast and the Northwest orientations. It also has less exposed surface area, and therefore fewer amounts of heat are lost from the building envelope.

\section{B. Refurbishment Scenarios}

As the energy consumption of a building is affected by its construction elements, alternative techniques must be used to create a comfortable indoor environment, which at the same time will achieve energy conservation $[11,12,13,14]$. Therefore, the retrofitting interventions are restricted on the building envelope, while the electromechanical systems for heating and cooling remained the same. Thus, a retrofitting scenario was developed using energy conservation measures (ECMs) that were based on the new requirements of the EPBD Directive [9] enforced on the beginning of 2014.

In order to meet the minimum requirements for the building envelope for EPBD Directive [9]; $30 \mathrm{~mm}$ of thermal insulation (expanded polystyrene) is added externally on the walls, $50 \mathrm{~mm}$ of thermal insulation (expanded polystyrene) is also installed internally on the horizontal ceiling and finally, the windows are replaced with new double glazed windows. After the retrofitting interventions, the new U-Values of the building envelopes of all the three Terrace Family Houses stay the same and are calculated as shown on Table 2.

Table 2 THERMAL CHARACTERISTICS OF THE BUILDING ENVELOPE FOR $\mathrm{TFH}$

\begin{tabular}{|c|c|}
\hline Construction Element & U-Value W/(m² $\mathrm{k})$ \\
\hline Pitched roof with horizontal ceiling & 0.60 \\
\hline External Walls & 0.69 \\
\hline Floor in contact with the ground & 0.91 \\
\hline Double glazed windows & 3.23 \\
\hline
\end{tabular}

Using these EMCs, the TFH01 has moved up two EPC categories from (F) to (D). The calculated total Primary Energy Consumption for the refurbishment scenario of TFH01 is now $319.36 \mathrm{kWh} /(\mathrm{m} 2 \mathrm{a})$ which means a saving percentage of $39.23 \%$. The total Delivered Energy Consumption is reduced to $149.08 \mathrm{kWh} /(\mathrm{m} 2 \mathrm{a})$, from which the energy consumption of heating is $51.98 \mathrm{kWh} /(\mathrm{m} 2 \mathrm{a})$, with savings up to $42.40 \%$ and of cooling is $75.36 \mathrm{kWh} /(\mathrm{m} 2 \mathrm{a})$ with savings up to $44.60 \%$. Lighting and domestic hot water consumption remained the same. The Carbon Dioxide emissions are calculated at $90.93 \mathrm{kgCO}_{2} /(\mathrm{m} 2 \mathrm{a})$, presenting a reduction of $43 \%$. After this refurbishment scenario, the dwelling has an average energy saving percentage up to $42.30 \%$ (as shown in figure 7).

The installation and construction cost for the refurbishment scenario for the first Terrace Family House (TFH01) was approximately $€ 7,090$ based on the current market values. The refurbishment 
scenario for the TFH01 has a payback period of 2 years only. The operational cost savings reach $€ 3,591$ per year. The pay-back period was calculated using the official tool published by the Ministry of Energy, Commerce, Industry and Tourism of Cyprus for the cost optimal [10] EMCs.

Using the same EMCs, the TFH02 has also moved up two EPC categories from (E) to (C). The calculated total Primary Energy Consumption for the refurbishment scenario of $\mathrm{TFHO2}$ is now $212.17 \mathrm{kWh} /\left(\mathrm{m}^{2} \mathrm{a}\right)$ and this means a saving percentage of $47.50 \%$. The total Delivered Energy consumption is reduced to $112.44 \mathrm{kWh} /\left(\mathrm{m}^{2} \mathrm{a}\right)$, from which the energy consumption for heating is $51.13 \mathrm{kWh} /(\mathrm{m} 2 \mathrm{a})$, with savings up to $44 \%$ and as for cooling is $32.58 \mathrm{kWh} /(\mathrm{m} 2 \mathrm{a})$ with savings up to $61.87 \%$. Lighting and domestic hot water consumption remained the same.

The Carbon Dioxide emissions are calculated at $59.11 \mathrm{kgCO}_{2} /\left(\mathrm{m}^{2} \mathrm{a}\right)$, presenting a reduction of $47.72 \%$. After the refurbishment scenario, the TFH02 has an average energy saving percentage of $50.27 \%$ (as shown in figure 7). The installation and construction cost for the refurbishment measures for the second Terrace Family House (TFH02) was approximately $€ 6,665$ based on the current market values. The refurbishment scenario for the TFH02 has a pay-back period of 2.5 years only. The operational cost savings reach $€ 2,840$ per year.

Finally, using the same EMCs the TFH03 has moved up two EPC categories from (F) to (D). The calculated total Primary Energy Consumption for the refurbishment scenario of TFH03 is now $212.17 \mathrm{kWh} /$ $\left(\mathrm{m}^{2} \mathrm{a}\right)$ and this means a saving percentage of $36.64 \%$. The total Delivered Energy Consumption is reduced to $190.47 \mathrm{kWh} /\left(\mathrm{m}^{2} \mathrm{a}\right)$, from which the energy consumption for heating is $83.38 \mathrm{kWh} /\left(\mathrm{m}^{2} \mathrm{a}\right)$, and for cooling is $82.30 \mathrm{kWh} /\left(\mathrm{m}^{2} \mathrm{a}\right)$ with savings of $41.85 \%$ and of $40.97 \%$ respectively. Lighting and domestic hot water consumption remained the same. The Carbon Dioxide emissions are calculated at $107.21 \mathrm{kgCO}_{2} /\left(\mathrm{m}^{2} \mathrm{a}\right)$, presenting a reduction of $36.39 \%$. After the refurbishment scenario, the TFH03 has an average energy savings percentage of $38.96 \%$ (as shown in figure 7 ).

\section{Saving Percentage per Terrace House}

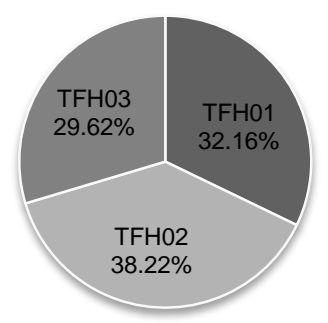

Fig .7. Average Saving Percentages for each Terrace House (TFH01, TFH02 and TFH03)

The installation and construction cost for the refurbishment measures for the third Terrace Family House was approximately $€ 7,545$ based on the current market values. The refurbishment scenario for the TFH03 has a payback period of 2 years only and the operational cost savings reach $€ 4,514$ per year. As shown on Figure 8 the first Terrace Family House (TFH01) has a Primary Energy Consumption reduction of $39.23 \%$, the second Terrace Family House (TFH02) has the highest percentage of Primary Energy Consumption reduction of $47.53 \%$; whereas the third Terrace Family House (TFH03) has the lowest reduction percentage of $36.60 \%$. The operational cost as calculated by the national method of cost optimum is divided in fuel (oil/diesel) consumption and electricity consumption. Even though the payback period for all three dwellings was between 2-2,5 years, the $\mathrm{TFH} 03$ has the largest operational cost saving of $€ 4,514$.

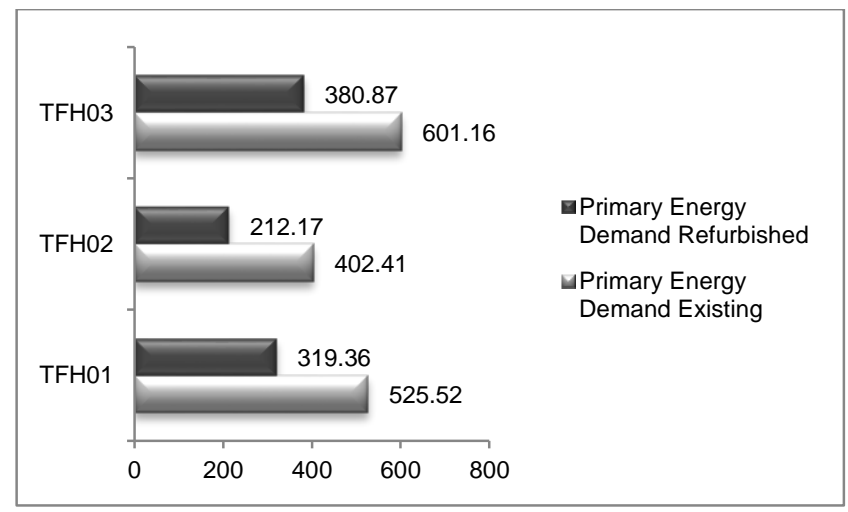

Fig .8. Calculated Primary Energy Consumption for the existing and the refurbishment for TFH01, TFH02 and TFHO3

Although the TFH03 has the highest installation and construction cost amongst the buildings under study, it has the largest savings due to the reduction in litres 
of oil consumed during the heating season. The TFH01 and TFH02 have larger savings on electricity consumption; yet electricity has a lower price per $\mathrm{kWh}$. The TFH02 has the smallest operational cost savings of $€ 2,839$ due to the fact that it has a fewer calculated savings in both electricity and oil consumption. Furthermore, TFH02 was classified one category higher than the TFH01 and TFH03.There were fewer savings due to the fact that the same EMCs were applied on all three dwellings and the TFH02 initially had less energy consumption, so there was less to save [15].

\section{CONCLUSION}

The study was performed in order to model the energy performance of a terrace family house typology complex. The scope was to compare the variance in energy consumption of similar units within the complex, which differ in terms of their orientation and their exposed facades areas. In this framework, an energy-retrofitting scenario was developed based on interventions on the building envelope of the dwellings to meet the minimum standards for the thermal envelope of the latest EPDB requirements. Indeed, the comparative studies of the energy consumption of the three terrace houses under study, prior the refurbishment interventions, show that the orientation of the surface areas of the units and their fenestration are determining factors for their energy consumption.

The results of the simulations, adopting retrofitting technics, indicate that the application of thermal insulation on the building envelope could have a significant impact on the buildings' performance. By introducing simple retrofitting interventions, such as $30 \mathrm{~mm}$ of external thermal insulation on the walls, $50 \mathrm{~mm}$ of thermal insulation on the roof and better double glazing of the end house of the Terrace complex, facing North East to South West, achieved a reduction of $39.23 \%$ in Primary Energy Consumption, $43 \%$ on $\mathrm{CO}_{2}$ emissions, $42.4 \%$ for heating and $44.64 \%$ for cooling. With the same interventions, the middle unit of the building had a calculated decrease of $47.53 \%$ in Primary Energy Consumption, $47.72 \%$ on $\mathrm{CO}_{2}$ emissions, $44 \%$ for heating and $61.87 \%$ for cooling. The application of the same energy conservation measures on the end unit of the Terrace complex facing northeast and northwest, had a calculated decrease of $36.60 \%$ in Primary Energy Consumption, $36.39 \%$ on $\mathrm{CO}_{2}$ emissions, $41.85 \%$ for heating and $40.97 \%$ for cooling. The Energy Performance Certificate (EPC) category for the three Terrace Family Houses was raised by two classes; the First and the Third were upgraded from (F) to (D) category; whereas the second was upgraded to category $(E)$ from $(C)$. The payback period varies between 2 and 2,5 years; whereas the TFH03 has the largest operational cost savings, followed by the TFH02 and the TFH01 which have the lowest operational cost saving.

The calculated savings vary from one dwelling to another. This is directly related to the existing energy consumption, which is a result of the thermal capacity of the building envelope, the heating area, the electromechanical systems as well as the location and orientation of each dwelling. Since the dwellings have the same thermal characteristics and thermal capacity of the building envelope, heating area and electromechanical systems, it is concluded that the location within the terrace complex and the orientation of each dwelling exert high impact on the savings of their energy consumption. It is therefore imperative to take these aspects into consideration at the design and setting stages of the buildings. Furthermore, the poor energy performance of the existing national residential building stock, especially those dwellings that were built before the enforcement of the European Directives, is evident. The urgency for immediate actions and simple retrofitting guidelines to improve the performance of the buildings' envelope and their energy consumption is confirmed.

\section{REFERENCES}

[1] NATO Science Series (2005) Thermal Energy Storage for Sustainable Energy Fundamentals, Case Studies and Design. Volume 234 pp. Preface ix.

[2] Meijer, F. Itard, L. Sunikka-Blank, M. (2009) Comparing European Residential Building Stocks: Performance Renovation. Building Research \& Information pp. 533-551.

[3] Ilaria Ballarini, Vincenzo Corrado (2009) Application of Energy Rating Methods to the Existing Building Stock: Analysis of Some Residential Buildings in Turin. pp. $790-800$.

[4] Konstantinou, T., Knaack, U. (2013) An Approach to Integrate Energy Efficiency Upgrade into Refurbishment Design Process, 
Applied in Two Case Study Buildings in Northern European Climate. Energy and Buildings 59, pp.301-309.

[5] Konstantinou, T., Knaack, U. (2011) Refurbishment of Residential Buildings: A Design Approach to Energy-Efficiency Upgrades. Procedia Engineering 21, pp. 666 675.

[6] IEE EPISCOPE Project: http://episcope.eu/index.php?id=97

[7] Typology of the Building Stock in Cyprus published (May 2012). Statistical Service of Cyprus.

[8] http://www.mcit.gov.cy/mcit/mcit.nsf/dmlperform ance_gr/dmlperformance_gr? (Accessed 20 November 2014) OpenDocument

[9] Directive2002/91/EC:http://eurlex.europa.eu/legacontent/EN/TXT/?uri=CELEX: 32002L0091

[10] Costoptimaltool:http://www.mcit.gov.cy/mcit/mcit .nsf/All/E074577C58AD9EFCC22575B60047BE A8? OpenDocument.

[11] DK Serghides, MC Katafygiotou (2013). The
Role of Materials in the Energy Efficient Retrofitting of Traditional Buildings. Materials and Processes for Energy: Communicating Current Research and Technological Developments pp. 978-84.

[12] Katafygiotou, M. C., \& Serghides, D. K. (2014). Analysis of Structural Elements and Energy Consumption of School Building Stock in Cyprus: Energy Simulations and Upgrade Scenarios of a Typical School. Energy and Buildings, 72, 8-16.

[13] Serghides D.K., Georgakis C., (2012). The Building Envelope of Mediterranean Houses Optimisation of Mass and Insulation. Journal of Building Physics, Volume 36 No1, ISSN: 17442591. Pp.83-98.

[14] Serghides, D. et al (2014). Energy Efficient Refurbishment of Existing Buildings: A Multiple Case Study of Terraced Family Housing. World Renewable Energy Congress 12- WREC XIII Aug. 2014 p.23.

[15] Serghides D.K., (2009). Optimisation of Insulation on Mediterranean Houses. ICPSR Journal: ISESCO Science and Technology Vision, Volume 5, Issue $n^{\circ}$ 8- Novembre 2009. Pp.79-83. 